\title{
PROSES PERCERAIAN DALAM PERSPEKTIF MARTIN BUBER
}

\author{
Imanuel Teguh Harisantoso \\ Fakultas Teologi Universitas Kristen Satya Wacana \\ imanuel.harisantoso@uksw.edu
}

\begin{abstract}
Divorce in Indonesia is increasing from time to time. This is an indisputable social fact. This research will analyze how the divorce process occurs and how a husband or wife sees their partner from Martin Buber's perspective through a philosophical approach. Divorce is a process leading to separation. Starting from a crisis and prolonged domestic conflict, in the end, it brings a new "perspective" towards their partner. In Buber's perspective, the husband and wife relationship could be said to be in the I-Thou pattern before the conflict. Husbands or wives see their partner as a self-image of their existence as a person, but the family crisis leads them to the l-It pattern, which sees partners as things. The crisis impacts changing the pattern of relations from integrative relationships to segregative and separate ones. The separation between husband and wife begins with self-construction by the "strong" party to their partner, who is in an inferior position. This negative self-construction creeps into a social construction, which impacts the stigmatization of the inferior as the party to blame. This stigma against a partner as "It" facilitates the separation process that leads to divorce.
\end{abstract}

Keywords: divorce proceedings, marital spouse, social construction, stigmatization, Martin Buber

\begin{abstract}
Abstrak. Perceraian di Indonesia semakin meningkat dari waktu ke waktu. Ini merupakan fakta sosial yang tidak terbantahkan. Melalui pendekatan filosofis penelitian ini akan menganalisa bagaimana proses perceraian terjadi dan bagaimana suami atau istri melihat pasangannya dalam perspektif Martin Buber. Perceraian adalah sebuah proses menuju perpisahan. Bermula dari sebuah krisis dan konflik rumah tangga yang berkepanjangan, pada akhirnya menghadirkan "sudut pandang" baru terhadap pasangannya. Sebelum konflik, dalam perspektif Buber, relasi suami istri dapat disebut berada pada pola I-Thou. Suami atau istri melihat pasangannya sebagai gambar diri atas keberadaannya sebagai seorang pribadi, tetapi krisis keluarga membawanya pada pola I-It yang memandang pasangan sebagai things. Krisis berdampak pada perubahan pola relasi dari relasi yang bersifat integratif menuju pola relasi segregatif dan sparatif. Proses perpisahan suami istri tersebut dimulai dengan adanya konstruksi diri oleh pihak yang "kuat" kepada pasangannya yang berada pada posisi inferior. Konstruksi diri negatif ini menjalar menjadi konstruksi sosial yang berdampak pada stigmatisasi pihak inferior sebagai pihak yang patut dipersalahkan. Stigma terhadap pasangan sebagai It inilah yang memperlancar proses separasi yang berujung pada perceraian.
\end{abstract}

Kata Kunci: proses perceraian, suami-istri, konstruksi sosial, stigmatisasi, Martin Buber

Tren perceraian semakin meningkat tiap tahunnya. Pada tahun 2018, angka perceraian di Indonesia mencapai angka 408.202 kasus, meningkat 9\% dibandingkan tahun sebelumnya. (Jayani, 2020). Menurut data Badan 
Pengadilan Agama (Badilag) Mahkamah Agung, pada tahun 2019 terdapat 604.997 kasus permohonan perceraian di seluruh Indonesia, dari jumlah tersebut $79 \%$ permohonan telah dikabulkan pengadilan. Artinya, terdapat 479.618 pasangan pernikahan resmi bercerai. (Lahati, 2020). Giddens (2001) menyebutnya buah dari revolusi budaya peraturan perkawinan yang sangat bebas sebagaimana terekam dalam undang-undang perkawinan. Perkawinan dianggap sebagai kontrak kerja yang dapat diakhiri jikalau suami istri samasama menginginkannya. Bahkan jika salah satu pasangan keberatan, perceraian dapat diterima sebagai tanda lenyapnya perasaan saling mencintai dalam perkawinan.

Perkawinan dan perceraian seolah menjadi sisi mata uang yang tidak terpisahkan. Di mana ada perkawinan, pasti terdapat warna lain perkawinan dalam dinamikanya yang berujung pada perceraian. Seperti halnya perkawinan, perceraian juga merupakan suatu proses yang di dalamnya menyangkut banyak aspek seperti: emosi, ekonomi, sosial, dan pengakuan secara resmi oleh masyarakat melalui hukum yang berlaku. (Karim, 2004).

Dalam sepuluh tahun terakhir terdapat banyak studi mengenai perceraian. Namun dari berbagai kajian tersebut belum ada yang fokus pada "proses perceraian". Bagaimana perubahan besar dapat terjadi dalam kehidupan rumah tangga: bermula dari kehidupan yang bahagia, melihat pasangan sebagai dirinya sendiri seperti halnya konsep pola relasi I-Thou 
Buber, lalu bergeser dalam hubungan tanpa rasa emosioanl $I-I t$, yang cenderung melihat pasangannya sebagai things atau bahkan liyan. Deskripsi pergeseran cara pandang ini yang dapat disebut dengan mandegnya integrasi perkawinan terhadap pasangan tampaknya penting untuk mengurai benang kusut yang bernama perceraian.

Kajian terhadap persoalan perceraian ada yang dilakukan sebagai upaya untuk menggali faktor-faktor penyebab perceraian. (Matondang, 2014). Usaha tersebut dilakukan baik oleh pihak pemerintah, misalnya yang terjadi di Ponorogo (Nasution, 2019), maupun yang dilakukan oleh lembagalembaga keagamaan seperti gereja (Harisantoso, 2019). Namun perlu diakui tidak mudah mengurai benang kusut persoalan kehidupan rumah tangga ini. Hampir dalam banyak kasus yang terjadi para pelaku perceraian selalu beralasan bahwa apa yang dilakukan merupakan pilihan yang paling rasional (Oiladang, 2012) dalam menyelesaikan masalah keluarga.

Munculnya intensi negatif berupa kekerasan dalam rumah tangga, ketidaksetiaan suami istri dan pasangan yang tidak bertanggungjawab (Khumas et al., 2015) semakin membebani beratnya mempertahankan kebahagiaan dan keutuhan rumah tangga. Harisantoso (2019) melakukan amatan terhadap masyarakat Jember dengan berbasiskan masyarakat agama (anggota Gereja GKJW) membagi faktor penyebab perceraian dalam dua bagian, yaitu faktor utama dan pendukung. Faktor utama meliputi: 
dukungan sosial masyarakat sekitar, tuntutan administrasi kependudukan, konversi agama yang "belum tuntas" dan "menikah paksa", sedang faktor pendukung meliputi: tanggungjawab, pihak ketiga, konflik rumah tangga dan komunikasi.

Dari sudut ilmu komunikasi, perceraian memberikan masing-masing dampak negatif berupa perasaan minder, menutup diri, kehilangan figure ayah dan menjadi pribadi yang keras (Febrianita \& Desiningrum, 2017; Hartini, 2019). Meskipun di sisi lain, di tengah derasnya "tekanan" sosial dan psikologis dari perceraian, para "pelaku perceraian" tetap berusaha untuk membangun komunikasi yang baik dengan anak-anak yang menjadi hak asuhnya. Mereka berusaha untuk membangun komunikasi positivity (interaksi yang menyenangkan), keterbukaan dan rutin berkomunikasi, serta komitmen untuk terus menjaga "relasi" yang baik. (Wulandari, 2016). Meskipun demikian, persoalan yang diakibatkan oleh perceraian tidak hanya berpengaruh terhadap pasangan suami istri, teristimewa kepada anak-anak, tetapi juga masyarakat secara umum. Pasca perceraian, anak tidak secara langsung menunjukan trauma yang dihubungkan oleh terputusnya perkawinan ayah dan ibu, tetapi memiliki dampak negatif yang berkepanjangan. (Darmawati, 2017; Köstenberger \& Jones, 2004).

Tulisan ini adalah kelanjutan dari kajian yang penulis lakukan tahun 2019 perihal perceraian. (Harisantoso, 2019). Pada bagian ini, secara khusus 
saya ingin mengkaji bagaimana proses sebuah perceraian terjadi dalam hubungan suami istri? Bagaimana suami dan atau istri "memandang" pasangannya? Proses tersebut dilihat dalam perspektif Martin Buber yang secara radikal melihat relasi manusia secara filosofis-teologis.

\section{METODE}

Kajian ini menggunakan pendekatan penelitian kepustakaan yang di dalamnya meliputi kritik pemikiran, kritik terhadap peristiwa-peristiwa tertentu baik peristiwa agama maupun peristiwa sosial, dan dapat pula penelitian tentang karya atau naskah tertentu. (Kaelan, 2010). Untuk menganalisa secara komprehensif, semua sumber data mendapatkan perhatian yang sama besar. Sumber data adalah buku, jurnal-jurnal ilmiah, hasil-hasil penelitian, catatan, termasuk dokumen-dokumen hukum yang berkaitan dengan ketetapan pengadilan yang memutus perceraian. Dokumen-dokumen tersebut akan dianalisa dalam perspektif pemikiran Martin Buber.

\section{I-Thou dan I-It Martin Buber}

Martin Buber (1878-1965), seorang filsuf dan sekaligus teolog keturunan Yahudi yang memperkenalkan pemikiran eksistesi manusia dalam relasi mysticism. la membaginya menjadi dua model, yaitu relasi I-Thou dan I-It, yang tercermin dengan jelas dalam tulisannya, "Bagi manusia, dunia ada dua, sesuai dengan dua sikapnya. Begitu juga sikap manusia ada dua, sesuai dengan dua sifat dari kata-kata utama yang diucapkannya" (Buber, 
1937, hal. 3). Dalam mewujudkan eksistensi dirinya sebagai mahluk yang berelasi (homo socios) manusia tidak dapat mengisolasi diri, tinggal dalam kesendiriannya. Komunikasi dengan orang lain menjadi bagian fundamental dari karakter jiwa manusia, sebagaimana disampaikan oleh Atkinson:

Manusia tidak dapat diisolasi, karena hal ini bertentangan dengan disposisinya. la harus berinteraksi dengan orang lain dan dengan cara itulah jiwa-jiwa dibawa ke dalam relasi nyata satu sama lain. Keterbukaan terhadap jiwa (orang) lain adalah bagian dari karakter dasar jiwa, dan untuk itulah jiwa diciptakan; keberadaannya dilahirkan sangat berkaitan dengan keluarga. Begitu juga hidup terdiri dari kombinasi yang terus diperbarui dengan jiwa-jiwa-relasi antar manusia." (Atkinson, 2014, hal. 184).

Relasi model Buber yang pertama adalah I-Thou, yaitu relasi yang menampilkan seluruh kodrat komunikasi manusia yang paling mungkin. Komunikator tidak mempunyai obyek, ataupun batasan dengan yang lain, karena tetap dalam relasi itu sendiri. "Ketika Thou diucapkan, pembicara tidak memiliki apa-apa terhadap objeknya. Karena di mana ada sesuatu di situ ada hal lain.... Thou tidak memiliki batas.... Tapi dia menentukan pendiriannya dalam suatu hubungan." (Buber, 1937, hal. 4). Relasi I-Thou memandang rekan bicara tidak hanya sebagai "engkau", melainkan meneguhkan keberadaan "Aku". Aku adalah "Aku" ketika berelasi dengan "engkau". Tanpa "engkau" tidak ada "Aku". "Engkau" bukanlah "non-Aku" ("lawan Aku"). "Engkau" bukan hanya lawan ber-relasi, tetapi mengambil peran sebagai "Aku yang lain", karena "engkau" makin memungkinkan "Aku" subjek. (Riyanto, 2018, hal. 215). 
Selanjutnya, relasi I-It. Jikalau I-Thou melihat partner komunikasinya sebagaimana keutuhan kondisinya, sedangkan I-It tidaklah demikian. "The Primary word I-Thou can only be spoken with the whole being, sebaliknya the primary word I-It can never be spoken with the whole being." (Buber, 1937, hal. 3).

Konsep relasi yang dikembangkan Buber dalam I-Thou dan I-It bukan terletak pada subyek dan obyek dari relasi tersebut. Misal: I-Thou itu menunjuk pada relasi antara manusia dengan sesamanya manusia, sedang model I-It terjadi antara manusia dan benda (pohon, rumah, atau yang lainnya), tidak. Perbedaan radikal tersebut tidak terletak pada obyek relasi, melainkan pada relasi itu sendiri dalam cara berhubungan. Perbedaan kedua model relasi Buber nyata dalam intimasi relasi yang dibangun. "Primary words do not signify things, but they intimate relations." (Buber, 1937, hal. 3).

Buber menggambarkan dunia manusia dalam "words" (kata-kata), dan menterjemahkan segala macam tindakannya dalam "primary words". Jika keduanya diringkas, "primary words" itu adalah kombinasi, sebuah relasi kesadaran dan komunikasi kedekatan yang tidak melihat yang lain sebagai "things".

Meskipun frasa filosofis Buber seringkali sulit dicerna, tetapi karyanya memberikan pencerahan religiusitas nilai dialogal "Aku" manusia. Karena religiusitas bersifat relasional, benih-benih religiusitas hanya akan tumbuh 
dalam relasi dialogal. Di luar semua itu hanyalah pembenaran diri semata. Relasi yang dimaksudkan adalah relasi "Aku Engkau Tuhan". Relasi I-Thou (Tuhan) hanya akan mungkin terjadi apabila terjadi relasi I-Thou (sesama manusia) dan religiusitas menjadi sangat mungkin apabila manusia memiliki relasi perdamaian (seutuhnya) dengan sesamanya. (Riyanto, 2018).

\section{HASIL}

\section{Krisis Relasional}

Komunikasi interpersonal memiliki peran penting dalam membina dan memelihara relasi perkawinan. Komunikasi yang intens yang melibatkan baik unsur ekstrinsik dan intrinsik sebagai pasangan diadic akan menentukan kualitas relasi itu sendiri. Komunikasi yang buruk dapat menyebabkan konflik rumah tangga; dan konflik yang berkepanjangan akan mempersepsi pasangan dalam apriori negatif.

Bagan 1. Proses Relasi Suami Isteri Menuju Perceraian

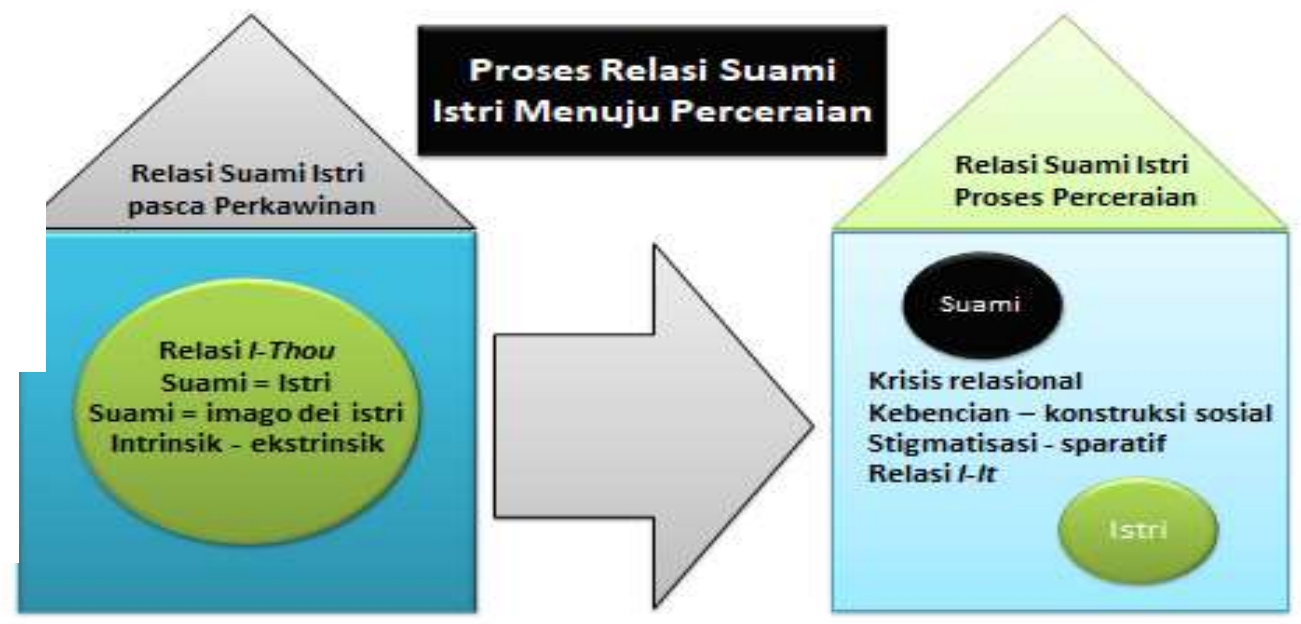


Konflik selalu mengakibatkan berkurangnya perhatian intrinsik dan ekstrinsik, termasuk hubungan seksual. Permasalahan sekecil apapun dapat menjadi stimulan bagi konflik yang lebih besar. Relasi suami istri seperti ini, apabila tidak mendapatkan perhatian dan penanganan dengan baik dapat berakhir dengan perpisahan atau perceraian.

\section{Bermula Dari Krisis Menuju Kebencian (Konstruksi Identitas)}

Pada mulanya suami istri hidup rukun dan harmonis. Tetapi situasi relasi I-Thou seperti dalam perspektif Buber mulai mengalami pergeseran, ketika "krisis" rumah tangga terjadi. Perselisihan menjadi stimulan untuk melihat pasangan sebagai objek (things), bukan gambaran dirinya.

Berdasar studi atas dokumen-dokumen pengadilan yang menarasikan alasan disahkannya perceraian, tampak bahwa "saya" atau "l" selalu mempersepsi pasangan dalam secara negatif. Untuk dapat bercerai penggugat mengkonstruksi diri tergugat "sebagai yang tidak bertanggung jawab"; "sebagai pasangan yang tidak setia, selingkuh"; "tidak pernah memberikan nafkah wajib"; "berlaku kasar sehingga menyebabkan pertengkaran dan konflik yang tidak bisa didamaikan" dan; "tidak bisa menyesuaikan diri dan semaunya sendiri, sehingga menghadirkan perbedaan prinsip yang pada akhirnya menimbulkan perselisihan yang berlarut-larut". Persepsi "Aku" terhadap pasangan dalam stigma negatif, meskipun tidak 
sesuai dengan kenyataan, akhirnya membentuk identitas diri bagi yang dipersepsikan. Sebab itu, jadilah "suami atau istri yang tidak bertanggung jawab"; "suami atau istri tukang selingkuh" ataupun; "suami yang kasar". Konstruksi diri oleh pasangan, biasanya dilakukan oleh yang "kuat", dalam hal kasus pengadilan yang bertindak sebagai konstruktor adalah Penggugat. Konstruksi diri inilah yang pada akhirnya menghadirkan stigma terhadap yang distigmatisasi.

\section{Stigmatisasi Berujung pada Separasi}

Meminjam istilah Goffman bahwa persepsi negatif yang dilakukan "Aku" terhadap "pasangan" disebut dengan "stigma" atau "stigmatisasi". Pasangan yang mendapatkan konstruksi negatif cenderung dalam posisi inferior. Stigmatisasi merupakan bentuk reaksi terhadap pasangan yang dipandang sebagai yang tidak sesuai dengan "norma" yang diharapkan. Stigma mengacu pada perbedaan identitas sosial yang menjadi atribut dan membuatnya berbeda dengan yang lain. Kategori dan atribut yang melekat pada suami istri yang dipersepsikan membentuk "identitas sosial". Dampak kategorisasi yang dilabelkan, menghadirkan sebuah tuntutan terhadap apa yang dipikirkan, baik dapat dipenuhi maupun tidak terpenuhi sebagaimana yang diasumsikan oleh pelabel. (Goffman, 1963, hal. 2).

Stigma merupakan kerangka konseptual yang problematis. Saya melihat stigma negatif yang dilabelkan suami istri terhadap pasangannya 
hanyalah upaya bernarasi untuk meraih apa yang menjadi harapannya. Stigma negatif hanyalah tools untuk mendapatkan dukungan sosial dari keluarga dan lingkungan, untuk mencapai separasi perkawinan yang menurutnya tidak layak untuk dipertahankan.

\section{PEMBAHASAN}

\section{Relasi Suami Istri: dari I-Thou menuju I-It}

Buberian melihat relasi suami istri dalam kemanunggalan pada relasi IThou, seperti kata bijak, "Inilah dia tulang dari tulangku dan daging dari dagingku...." (Kej 2:23). Relasi I-Thou memposisikan suami istri sebagai "Aku-Engkau" subyek terhadap subyek, yang melihat istri ataupun suami bukan sebagai satu kesatuan yang saling mengikat dan "keduanya menjadi satu daging" Kej 2:24). Suami adalah bagian kehidupan dari istri dan sebaliknya; suami menjadi kesempurnaan istri dan istri menghadirkan kesempurnaan suami sebagai laki-laki. Suami mengikutsertakan keseluruhan eksistensi istri dalam dialog dengan dirinya. Dengan demikian relasi yang terbangun adalah mutualitas dan resiprokal.

Terdapat tiga konsep relasional I-Thou suami istri menurut Buber. Pertama, manusia pada prinsipnya bersifat relasional dan mudah dipengaruhi. (Atkinson, 2014). Manusia adalah ciptaan yang memiliki sifat ketergantungan satu sama lainnya. Relasi intim nampak dalam kehidupan rumah tangga setelah perkawinan digelar. Sebuah relasi disertai dengan 
toleransi yang tinggi dan gairah seksual yang menggebu. Konflik atau pertengkaran dianggap hal yang wajar, sebagai bagian dari sebuah proses penyatuan kesepahaman yang bermuara pada intimasi kehidupan suami istri (Harisantoso, 2019).

Kedua, kehidupan suami istri selalu berada "between collectivism and individualism" (Atkinson, 2014). Kehidupan manusia berada dalam situasi problematik, untuk itu harus memilih dengan tepat "antara" individualisme ataukah kolektivisme. Buber menyatakan keberadaan individu adalah sebuah kenyataan dalam relasinya dengan individu yang lain demikian juga keberadaan manusia menjadi nyata ketika berada dalam komunikasinya dengan sesamanya manusia. "Fakta keberadaan individu adalah sejauh ia melangkah ke dalam hubungan yang hidup dengan individu lain.... Fakta mendasar keberadaan manusia adalah manusia dengan manusia lainnya." (Buber, 2002, hal. 240). Seorang laki-laki atau perempuan akan menemukan identitasnya justru ketika mereka berada dalam komunitas yang disebut keluarga. Dengan demikian komunitas keluarga memiliki makna penting bagi eksistensi laki-laki dan perempuan.

Terakhir, kesatuan perkawinan (Atkinson, 2014). Buber memahami kehidupan perkawinan memiliki keserupaan dengan identitas organik. Kesatuan suami istri yang dipersekutukan menjadi "satu daging" nampak ketika suami istri saling berbagi kasih. Buber juga memahami komunitas 
suami istri dalam perkawinan memiliki partisipasi yang besar dalam persekutuan manusia dengan Tuhan. Relasi suami istri memiliki dimensi pengalaman manusia yang paling fundamental dan justru dalam relasinya dengan orang lain individu mendapatkan kemanusiaanya yang utuh.

Model relasi $I$-Thou pada suami istri dapat berubah menjadi relasi $I-I t$ ketika hubungan rumah tangga melihat pasanganya sebagai obyek (Friedman, 1955) dan menurut apa yang dipersepsikan. Suami istri (I) menutup diri dari pasangannya $(I t)$ dan membiarkan apa yang dipikirkan tentangnya sebagaimana yang dikonstruksinya. Artinya relasi yang terjadi bukan lagi pada aras in between melainkan berdasar pada ego. Hal ini muncul, ketika persoalan demi persoalan datang silih berganti dan mereka mengalami kesulitan untuk mengelolanya.

Dalam relasi $l$-lt suami istri tidak melihat pasangannya sebagai subyek yang secara religiusitas segambar dengan citra Sang Khalik (Kej 1:27), tetapi subyek yang dipahami sebagai obyek. Sehingga relasi yang terbangun menjadi hubungan tanpa spirit, tanpa gairah dan roh. Buber menyebutnya, "But the separated It of institutions is an animated clod without soul, and the separated I of feelings an uneasily fluttering soul-bird. Neither of them knows man: institutions know only the specimen, feelings only the "object"; neither knows the person, or mutual life" (Buber, 1937, hal. 44; Friedman, 1955, hal. $63)$. 
Secara mekanikal kehidupan suami isteri yang demikian tidak ada gairah kekeluargaan. Kehidupannya hanya diikat oleh pernikahan yang memayungi kebersamaan mereka. Mutualisme relasi suami isteri tidak terjadi, karena mereka merasakan kesendirian dan ingin lepas dari relasi yang ada. Relasi I-It tidak mampu menembus relung hati pasangan dan tidak menghasilkan buah yang diharapkan sebagaimana I-Thou, tetapi terpisah dan stagnan (Buber, 1937) yang memperburuk hubungan itu sendiri.

Relasi I-It menurut Buber, "Aku" dalam kasus perceraian menjadikan dirinya sebagai pengambil inisiatif, menjadi rujukan dan memposisikannya sebagai yang benar, bersifat separasi dan pelepasan. Suami istri mengobyektifikasi pasangannya menjadi It (itu $=$ things) dengan cara menggunakan persepsi, pengalaman dan pendefinisian terhadap it yang memiliki tujuan atau makna (means) terhadap yang lain. Relasi semacam ini adalah sebuah hubungan yang parsial, terbatas dan cenderung tendensius, karenanya tidak bersifat utuh (whole). "Aku" suami istri selalu melihat pasangannya dalam pengertian aprioristic dan cenderung pada penghakiman (justification), yang berakhir pada perceraian.

\section{Proses menuju Perceraian}

Perspektif Buber melihat perceraian diawali oleh adanya perubahan pola relasi suami istri, dari I-Thou menuju I-It. Pada awal perkawinan mereka berada dalam relasi I-Thou, tetapi setelah terjadi krisis keluarga, relasional 
bergeser menjadi I-lt. Memperhatikan pola relasional yang ada, dapat dikatakan bahwa perkawinan adalah "sebuah proses integrasi" menyatunya laki-laki dan perempuan dalam relasi diadic, sebaliknya perceraian merupakan mandegnya atau rusaknya "proses integrasi" suami istri.

Bagan 2. Proses Menuju Perceraian

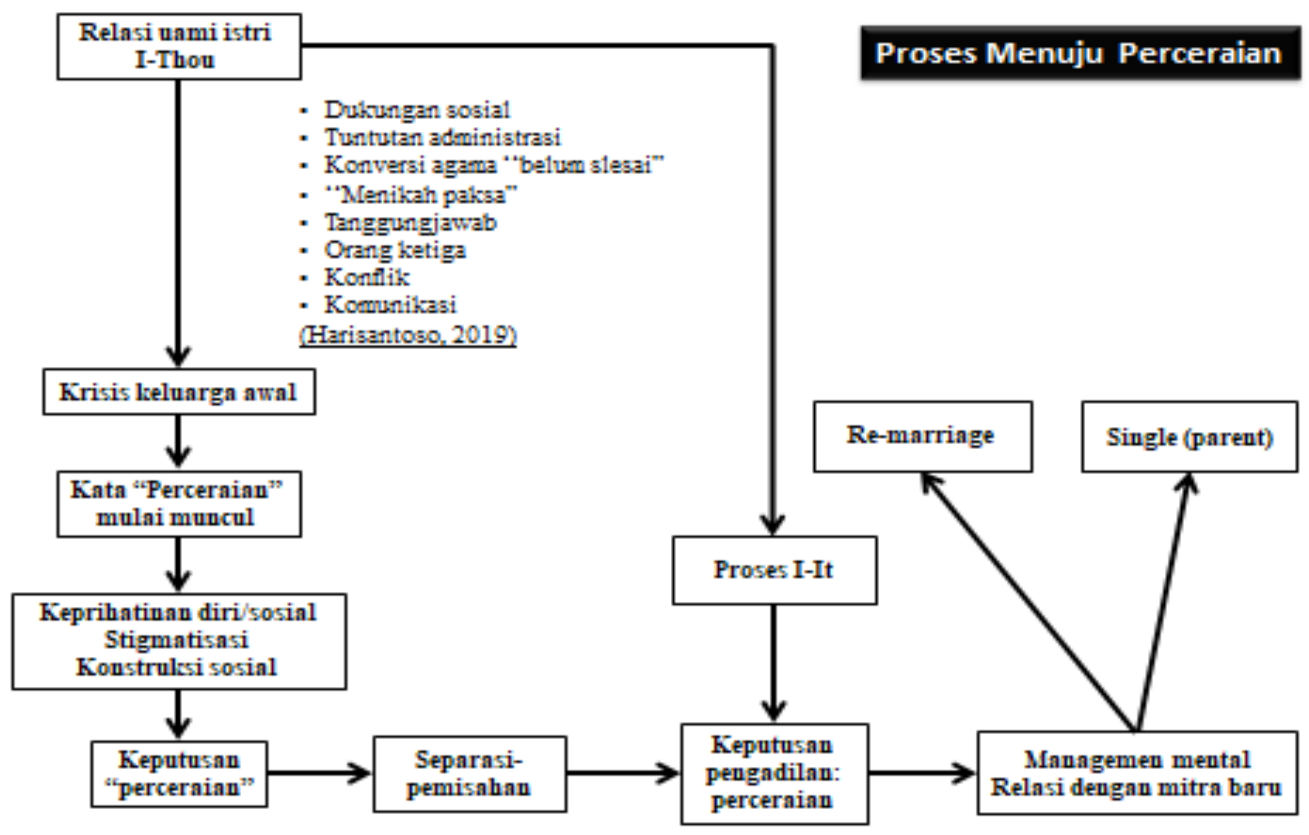

Bagaimana proses perceraian terjadi? Penulis melihat perubahan I dalam melihat pasangannya, Thou menjadi It menyebabkan mandegnya proses take and give. Dampak dari pergeseran pola relasi dalam persepektif Buber menyebabkan suami istri tidak mendapatkan "gambar diri" pada pasangannya. Mereka tidak menemukan sesuatu yang baik pada pasangannya sebagai pribadi, tetapi lebih sebagai things. Dalam situasi 
seperti itu Gulardi (1999) melihat akan memunculkan perasaan-perasaan sebagai berikut: pertama, mulai memaksakan kehendaknya sendiri atau egoisme pribadi; kedua, satu dengan yang lain saling mencari kesalahan pasangannya; ketiga, lebih memilih konflik daripada mencari jalan keluar untuk kepentingan bersama dan; terakhir, dampak dari relasional yang mempertahankan egoisme pribadi daripada penyelesaian konflik adalah mencoba untuk menunjukan kekuasaan dan superioritasnya.

Konflik adalah penampakan egoisme diri yang ingin menunjukan ke"aku"-an superioritas dan seolah-olah kebenaran yang diyakininya. Tindakan yang demikian semakin menenggelamkan relasi I-Thou, menghilangnya pujian serta penghargaan yang diberikan kepada pasangan. Padahal, pujian dan penghargaan, cinta kasih yang diberikan kepada pasangan suami istri merupakan dukungan emosional yang sangat diperlukan dalam suatu perkawinan. Dengan demikian menegaskan semakin menghilangnya perspektif Thou dan menekankan dimensi It yang lebih bersifat separasi dalam relasi suami istri. Artinya, relasi semacam ini akan mengakibatkan hubungan suami istri semakin jauh dari semangat perkawinan dan memperburuk capaian keharmonisan yang dibangun.

Ini dapat dikatakan sebagai kondisi mandegnya proses integrasi suami istri. Perubahan relasi $I$-Thou menjadi $I$-It semestinya dilihat sebagai "lampu kuning", alarm peringatan bahaya perceraian yang mengancam keutuhan 
rumah tangga. Relasi suami istri sedang mengalami krisis perkawinan yang serius. Mereka tidak lagi melihat pasangannya sebagai perwujudan dirinya, sebaliknya melihat pasangannya sekedar things yang jauh dari kata intimasi.

Untuk memudahkan deskripsi mengenai proses mandegnya integrasi perkawinan dalam perspektif Buber, baik untuk mengikuti pemikiran Atlee L. Stroup (1966) dan kemudian mengembangkan pemikirannya dalam menjelaskan fase-fase menuju perceraian sebagai berikut: pertama, pada fase awal perkawinan, relasional cinta kasih suami istri sangat nampak kebahagiaannya. Kehidupan suami istri selalu berada "between collectivism and individualism", mereka merasakan kehidupan suami istri merupakan sebuah kesatuan perkawinan. Apa yang dirasakan suami, seolah istripun turut merasakannya, susah maupun senang selalu menjadi tanggungan bersama sebagai keluarga. Dalam periode awal perkawinan, I (suami atau istri) selalu memandang Thou, yaitu pasangannya sebagai gambar dirinya. Inilah gambar ideal relasi suami istri, karenanya saya menyebut periode ini sebagai relasi I-Thou suami istri.

Kedua, berkurangnya respon kasih sayang. Hal ini disebabkan oleh adanya perbedaan yang sering terjadi di antara pasangan, konflik mulai muncul dan tidak terselesaikan dengan baik. Akibat relasional yang demikian, pasangan berusaha mencari kompensasi untuk kekurangan hubungan dalam beberapa kasus. Periode inilah awal pergeseran I-Thou menuju I-It. 
Ketiga, kemungkinan kata "perceraian" mulai disebutkan. Hal ini mempertegas hubungan yang terjadi dengan "inisiator" yang memulai keinginan tersebut dengan pasangannya yang mulai terpengaruh secara pasif oleh siklus perceraian. Periode ini didasari situasi inisiator yang merasa bahwa ia melihat pasangannya hanya sebatas things, dan tidak mungkin untuk membangun intimasi kembali seperti halnya relasional di awal perkawinan.

Keempat, munculnya keprihatinan sebelum diketahui oleh banyak orang. Keprihatinan relasional bermula dalam konteks relasional suami istri, tetapi kemudian berkembang mencari dukungan pada keluarga dan atau orang-orang dekat untuk mendapatkan dukungan atas tindakan yang dilakukan. Cerita solidaritas ini sangat penting sebagai alasan untuk menjaga diri. Sekali saja salah dalam mengelola keprihatinan ini, maka perkawinan tidak dapat dipertahankan lagi.

Kelima, kristalisasi I-It diwujudkan dalam keputusan perceraian yang dibuat, biasanya setelah perseteruan yang sangat panjang, meskipun beberapa kali keputusan dibuat tanpa pemikiran ke masa lampau. Relasional I-It lebih bersifat sparasi dan perpisahan, karena kristalisasi persepsi inilah yang memperkuat "keinginan" berpisah dari pasangannya.

Keenam, sebuah krisis yang diperparah dengan perpisahan. Memutuskan untuk berpisah dan atau bercerai adalah pengalaman traumatik 
yang berdampak serius dalam kehidupan berkeluarga, meskipun hal ini dianggap sebagai satu-satunya jalan terbaik dalam menyelesaikan persoalan yang ada. Dalam fase ini, pasangan melihat tidak ada jalan lain untuk memperbaruhi buruknya relasi suami istri, kecuali berpisah.

Ketujuh, keputusan perceraian menjadi kenyataan. Bisa jadi hal ini melalui periode yang panjang setelah penundaan dan perpisahan. Sebelum keputusan pengadilan menyatakan "bercerai" mereka sudah berpisah: pisah ranjang dan atau pisah tempat tinggal. Bisa saja istri pulang ke rumah orang tua atau sebaliknya, pihak suami yang meninggalkan rumah dengan berbagai alasan pembenarannya. Prosedur hukum dengan ketetapan pengadilan dibutuhkan sebelum tahap akhir adaptasi baru dimulai..

Kedelapan, periode manajemen mental dan rekonstruksi menutup kasus relasional yang menegangkan. Pasca keputusan pengadilan "bercerai" dan memastikan status hukum ikatan perkawinan, menjadi peluang baru untuk menjalin relasi baru secara sosial dengan lingkungan keluarga, masyarakat dan terkhusus "mitra baru" dengan kelonggaran sebagai pribadi yang tidak lagi terikat oleh sebuah cinta kasih duaan, diadic. Dalam fase ini, setiap pribadi dapat mengambil satu keputusan batin untuk tinggal dalam kesendiriannya ataupun membangun relasi personal dengan lawan jenis menuju hubungan remarriage.

\section{PENUTUP}


Perkawinan adalah sebuah ikatan integral, jasmani dan rohani antara seorang laki-laki dan perempuan. Dalam ikatan emosional jiwani dan ragawi itulah suami dapat melihat istrinya sebagai cerminan atas keberadaannya dirinya. Suami istri sebagai I melihat dirinya dalam pasangannya, sebagai Thou. Suami adalah perwujudan istri atau sebaliknya. Suami ada karena keberadaan istri, dan istri dapat disebut istri karena keberadaan suami.

Tetapi krisis rumah tangga menghadirkan sudut pandang berbeda dalam melihat pasangan. Krisis dan konflik menyebabkan suami istri melihat pasangannya cenderung sebagai things, objek yang tidak mampu menghadirkan ekspektasi keberadaan pasangan. Pola relasi pun bergeser, dari relasi I-Thou bergerak menuju I-It. Pasangan bukan lagi sebagai garwa melainkan objek yang menjadi stimulan sparasi. Proses pergeseran I-Thou menuju I-It inilah yang memaksa setiap pasangan suami istri berujung pada perpisahan perceraian.

\section{DAFTAR PUSTAKA}

Atkinson, J. C. (2014). Biblical and Theological Foundations of The Family: the domestic church. The Catholic University of America Press.

Buber, M. (1937). I and Thou. T \& T Clark.

Buber, M. (2002). Between Man and Man. Routledge \& Kegan Paul.

Darmawati. (2017). Perceraian dalam Perspektif Sosiologi. Jurnal Wawasan Keislaman Sulesana, 11(1), 64-78. https://doi.org/10.24252/v11i1.3548

Febrianita, C. F., \& Desiningrum, D. R. (2017). Relasi Anak Dan Ibu Pada Keluarga Yang Bercerai (Studi Kualitatif Fenomenologis). Jurnal EMPATI, 6(1), 70-73. 
Friedman, M. S. (1955). Martin Buber: The Life of Dialogue. The University of Chicago Press.

Giddens, A. (2001). Runway World: bagaimana globalisasi merombak kehidupan kita. PT Gramedia Pustaka Utama.

Goffman, E. (1963). Stigma: notes on the management of spoiled identity. Englewood Cliffs.

Gulardi, S. T. (1999). Perubahan Nilai di Kalangan Wanita Bercerai. In T. O. Ihromi (Ed.), Bunga Rampai Sosiologi Keluarga. Yayasan Obor Indonesia.

Harisantoso, I. T. (2019). Perceraian Warga GKJW Di Kabupaten Jember: Suatu Analisa Teori Pertukaran Sosial. Visio Dei: Jurnal Teologi Kristen, 59-78. https://doi.org/10.35909/visiodei.v1i1.5

Hartini, N. (2019). Complete Family and Teenager's Well-Being. Journal of Advance Research in Dynamical \& Control Systems, 11(5), 1302-1307.

Jayani, D. H. (2020). Ramai RUU Ketahanan Keluarga, Berapa Angka Perceraian di Indonesia? https://databoks.katadata.co.id/

Kaelan. (2010). Metode Penelitian Agama Kualitatif Interdisipliner. Paradigma.

Karim, E. (2004). Pendekatan Perceraian dari Perspektif Sosiologi. In T. O. Ihromi (Ed.), Bunga Rampai Sosiologi Keluarga (hal. 135-165). Yayasan Obor Indonesia.

Khumas, A., Prawitasari, Johana E., Retnowati, S., \& Hidayat, R. (2015). Model Penjelasan Intensi Cerai Perempuan Muslim di Sulawesi Selatan. Jurnal Psikologi, 42(3), 189-206. https://doi.org/10.22146/jpsi.9908

Köstenberger, A. J., \& Jones, D. W. (2004). God, Marriage, and Family: Rebuilding the Biblical. Crossway Books.

Lahati, T. (2020). Menggugah Nurani Ex Officio Hakim Terhadap Putusan Cerai Verstek Yang Berkeadilan Perempuan. https://badilag.mahkamahagung.go.id/

Matondang, A. (2014). Faktor-faktor yang Menyebabkan Perceraian dalam Perkawinan. Jurnal IImu Pemerintahan dan Sosial Politik UMA, 2(2), 141-150.

Nasution, R. D. (2019). Upaya Pemerintah Dalam Penanggulangan Perceraian Di Kabupaten Ponorogo. Jurnal Penelitian Kesejahteraan Sosial, 18(1), 1-11.

Oiladang, C. S. (2012). Perceraian Sebagai Pilihan Rasional: kasus 
perceraian di desa Tanah Merah, Kupang - NTT. Jurnal Sosiohumaniora: Jurnal IImu-ilmu Sosial dan Humaniora, 14(2), 235247. https://doi.org/10.24198/sosiohumaniora.v14i3.5493

Riyanto, A. (2018). Relasionalitas: filsafat fondasi interpretasi aku, teks, liyan, fenomen. Kanisius.

Stroup, A. L. (1966). Marriage and Family: A Developmental Approach. Division of Meredith Publishing Company.

Wulandari, O. (2016). Orang Tua yang Bercerai dan Anak (studi kualitatif deskriptif komunikasi antar pribadi antara orang tua yang memiliki hak asuh dengan anaknya). Komuniti: Jurnal Komunikasi dan Teknologi Informasi, 8(1), 3-18. https://doi.org/10.23917/komuniti.v8i1.2928 